\title{
Video-assisted debriefing technique for nursing simulation: how to proceed?
}

\author{
Técnica de debriefing videoassistida para simulação em enfermagem: como proceder? \\ Técnica de debriefing asistida por video para la simulación de enfermería: cómo hacerlo?
}

Juliana da Silva Garcia Nascimento ${ }^{a}$ (D)
Isabela Meira Pereira ${ }^{a}$ (ID
Daniela da Silva Garcia Regino ${ }^{b}$ (D)
Aline Roberta da Silva ${ }^{a}$ (D)
Jordana Luiza Gouvêa de Oliveira ${ }^{a}$ (D)
Maria Celia Barcellos Dalria

How to cite this article: Nascimento JSG, Pereira IM, Regino DSG, Silva AR, Oliveira JLG, Dalri MCB. Video-assisted debriefing technique for nursing simulation: how to proceed? Rev Gaúcha Enferm. 2021;42:e20190361. doi: https://doi.org/10.1590/19831447.2021.20190361 a Universidade de São Paulo (USP), Escola de Enfermagem de Ribeirão Preto. Ribeirão Preto, São Paulo, Brasil.

b Universidade Brasil (UB). Fernandópolis, São Paulo, Brasil.

\section{ABSTRACT}

Objective: To identify elements in scientific literature that make the video-assisted debriefing technique feasible in the teaching and learning process, in nursing simulation.

Method: Integrative literature review, conducted from May to July of 2019. Primary studies, with no time frame, were selected in Portuguese, English or Spanish, in the PubMed ${ }^{\circledast}$, Scopus ${ }^{\circledast}$, CINAHL and LILACS databases, using the Rayyan application. Qualitative analysis was adopted.

Results: 205 studies were initially identified, six of which were selected and categorized into: "Elements that make up the videoassisted debriefing technique";" "Benefits of using the video-assisted debriefing technique" and "Challenges of using the video-assisted debriefing technique".

Conclusions: The elements that made the video-assisted debriefing technique feasible in the teaching and learning process in nursing were concept, objectives, material resources and procedure. The main benefit was the immediate recognition of behaviors, and the challenge was the risk that the video would make debriefing tiring and humiliating.

Keywords: Students, nursing. Video recording. Simulation technique. Learning.

\section{RESUMO}

Objetivo: Identificar, na literatura científica, elementos que viabilizam a técnica de debriefing videoassistida no processo de ensino e aprendizagem, na simulação em enfermagem.

Métodos: Revisão integrativa da literatura, realizada de maio a julho de 2019. Selecionaram-se estudos primários, sem recorte temporal, em português, inglês ou espanhol, nas bases de dados PubMed ${ }^{\circledast}$, Scopus ${ }^{\oplus}$, CINAHL e LILACS, por meio do aplicativo Rayyan. Adotou-se a análise qualitativa.

Resultados: Identificaram-se, inicialmente, 205 estudos, sendo seis deles selecionados e categorizados em: "Elementos que compõem a técnica de debriefing videoassistida"; "Benefícios da utilização da técnica de debriefing videoassistida" e "Desafios da utilização da técnica de debriefing videoassistida".

Conclusões: Os elementos que viabilizaram a técnica de debriefing videoassistida, no processo de ensino e aprendizagem em enfermagem, foram: conceito, objetivos, recursos materiais e procedimento. 0 principal benefício foi o reconhecimento imediato de comportamentos, e o desafio foi o risco de o vídeo tornar o debriefing cansativo e humilhante.

Palavras-chave: Estudantes de enfermagem. Gravação em vídeo. Simulação. Aprendizagem.

\section{RESUMEN}

Objetivo: Identificar, en la literatura científica, los elementos que permiten la técnica de video debriefing asistida en el proceso de enseñanza y aprendizaje en la simulación de enfermería.

Métodos: Revisión integral de la literatura, de mayo a julio de 2019. Estudios primarios, sin corte temporal, en portugués, inglés 0 español, en PubMed ${ }^{\circledast}$, Scopus ${ }^{\oplus}$, CINAHL y LILACS, con la solicitud de selección de Rayyan. El análisis cualitativo.

Resultados: Se identificaron 205 estudios, seis de los cuales fueron categorizados como: "Elementos que componen la técnica de

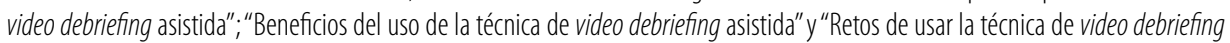
asistida".

Conclusiones: Los elementos de la técnica de video debriefing asistida fueron: concepto, objetivos, recursos materiales y procedimiento. El benefício fue el reconocimiento inmediato de los comportamientos, y el desafío fue el riesgo de que el video genere informes agotadores y humillantes.

Palabras clave: Estudiantes de enfermería. Grabación en video. Simulación. Aprendizaje. 


\section{口INTRODUCTION}

Nursing education must be consistent with the new job demands of the market, to overcome traditional and dichotomous aspects between what is taught and what is experienced, linking teaching to practice ${ }^{(1)}$. Hence the importance of incorporating new teaching strategies to part with the existing pedagogical barriers ${ }^{(1)}$ and, in this perspective, clinical simulation enables the articulation between theory and practice, and contributes to new learning opportunities ${ }^{(2)}$.

Defined as a teaching strategy that brings participants closer to reality, because it is based on situations that mimic real situations, clinical simulation is divided into three phases: preparation, participation and debriefing ${ }^{(3)}$. The preparation phase comprises two stages; in the first, called pre-simulation, teaching materials are sent for study by the participants, in the second, called pre-briefing/briefing, the participants are given guidance on the proposed scene, the objectives and the roles of each individual. The participation phase is defined by the realization of the scenario and the debriefing refers to a process of reflection on the experience, being one of the most important phases for the acquisition and retention of knowledge by the participant ${ }^{(2)}$. When properly conducted, debriefing promotes the development of skills $s^{(2)}$.

More than 30 methods and ten debriefing techniques have emerged in the past decade. However, there are still few well-designed studies focused on the development of competence in nursing through debriefing, a fact that contributes to this knowledge gap ${ }^{(4)}$.

The video-assisted debriefing technique (VAD) has been recommended by the literature to support learning and improve the quality of this process ${ }^{(5)}$, referring to the audiovisual response of the simulated session, which allows the review of experiences, to improve learning ${ }^{(6-9)}$. Although widely recommended and considered the gold standard for debriefing ${ }^{(10)}$, the VAD technique requires more in-depth scientific investigations, as the existing studies present variability in results regarding their effectiveness and educational benefits for nursing ${ }^{(11-12)}$. In addition, there is a lack of clarity about the guidelines for conducting $\mathrm{VAD}^{(6)}$, and few well-designed studies support its effectiveness in terms of students'learning outcomes ${ }^{(9,13-14)}$. In this way, the importance of this study lies in exploring the elements necessary to correctly proceed with the VAD technique, including its components, for the future development of protocols that support its use, based on scientific evidence. Considering the need for research on best practices on the VAD technique, the following guiding question arose: What elements are necessary to proceed with the VAD technique correctly and effectively? This study aimed to identify the elements in scientific literature that make the
VAD technique feasible in the teaching and learning process, in nursing simulation.

\section{METHODS}

This is an integrative review of the literature on the elements that make the VAD technique feasible, with the intention of identifying and understanding them, defining the best practices to develop this technique.

Six steps followed: (1) identification of the theme and selection of the hypothesis or research question; (2) establishment of criteria for inclusion and exclusion of studies; (3) definition of the information to be extracted from the selected studies/categorization of the studies; (4) evaluation of the studies included in the integrative review; (5) interpretation of results; (6) presentation of the synthesis of knowledge ${ }^{(15)}$.

The first step was identifying the theme, and selecting the research question through the PICO strategy (acronym for Patient-Intervention-Comparison-Outcomes), to describe the components of the following guiding question: What evidence is available in the literature about the elements needed to perform the VAD technique for learning in nursing simulation?

Searches were carried out from May to July 2019, with search strategies defined for each base. In PubMed ${ }^{\circledR}$ and Scopus ${ }^{\oplus}$, the descriptors Nursing, "Video Recording", "Simulation Training" and Learning, and the keyword debriefing were identified in Medical Subjects Headings (MESH), with the following search strategy: (Nursing OR"Economics, Nursing" OR "Education, Nursing" OR"History of Nursing" $O R$ "Legislation, Nursing") AND ("Video Recording"OR"Recording, Video"OR"Recordings, Video"OR"Video Recordings"OR Video recording OR Videorecordings OR "Audiovisual Recording" OR "Audiovisual Recordings" OR "Recording, Audiovisual"OR "Recordings, Audiovisual") AND (Debriefing) AND ("Simulation Training"OR "Training, Simulation"OR"Interactive Learning"OR "Learning, Interactive") AND (Learning OR Phenomenography OR "Memory Training" OR "Training, Memory".

In the Cumulative Index to Nursing and Allied Health Literature (CINAHL) database, the descriptors Nurses, "Students, Nursing", "Video recordings", Simulations and Learning, and the keyword debriefing were identified in titles, using the strategy search: (Nurses OR "Nursing Assistants" OR "Nursing Home Personnel") AND ("Students, Nursing" OR "Students, Nurse Midwifery" OR "Students, Nursing, Associate") AND (Video recordings OR Videodiscs) AND (Debriefing) AND (Simulations) AND (Learning).

In the Latin American and Caribbean Literature on Health Sciences database (LILACS), the descriptors "Students, Nursing", "Nurses; Teaching", "Video Recording", Simulation and 
Learning, and the keyword debriefing were identified in the Health Descriptors (DeCS), with the following strategies: ("Students, Nursing") AND (Nurses) AND ("Video Recording") AND (Debriefing) AND (Simulation) AND (Learning; ("Alunos de Enfermagem") AND (Enfermeiros) AND ("Gravação em Vídeo") AND (Debriefing) AND (Simulação) AND (Aprendizagem), ("Estudiantes, Enfermería") AND (Enfermeras) AND ("Grabación devideo") AND (Interrogatorio) AND (Simulación) AND (Aprendizaje). The term debriefing was used as a keyword, in view of the difficulty to find publications related to the objective proposed in this study, aiming, in this way, to relate the search to the intrinsic character of the theme.

Criteria for inclusion and exclusion of studies were established in the second stage of the integrative review, including primary studies, clearly exposing the components of the VAD technique, without delimiting the time frame, in Portuguese, English or Spanish, published in scientific journals and available electronically. Literature reviews, editorials, reviews, experience reports, case studies, theoretical reflections, dissertations, theses, monographs and abstracts published in event records were excluded. To select the studies, the articles were screened, with the evaluation of titles and abstracts by two professionals, using the Rayyan review application, which speeds up and makes this screening faster, using a semi-automation process that incorporates high level of credibility in the process ${ }^{(16)}$. Afterwards, the 10 studies that caused divergence among the researchers were handed over to a third party, responsible for making the decision of inclusion or exclusion, later proceeding to a full read and definition of the final sample. To extract the information from the studies, a validated instrument ${ }^{(17)}$ was used, featuring: title, level of evidence, country of origin, year of publication, objectives, method and results. The necessary elements for the execution of the VAD technique, its benefits and challenges for execution were also identified. Finally, there was the classification of the level of evidence of the studies ${ }^{(18)}$ and the presentation of their selection ${ }^{(19)}$ as shown in Figure 1.

\section{RESULTS}

Six primary studies were considered eligible to complete the final methodological phases of this integrative literature review. Chart 1 shows the main characteristics of the selected manuscripts.

Chart 2 shows the characteristics that make the video-assisted debriefing technique feasible, as well as its benefits and challenges.

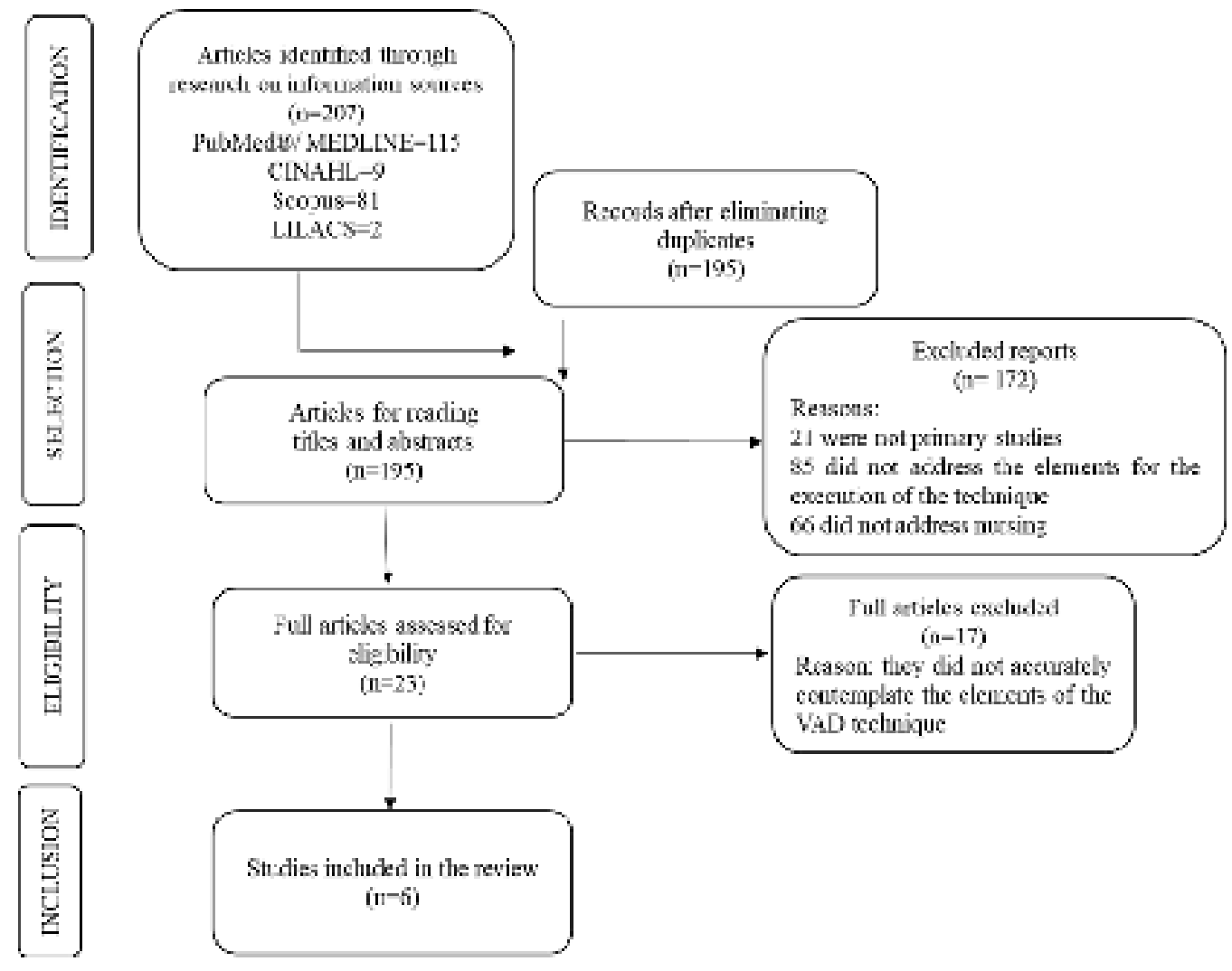

Figure 1 - Presentation of the study selection flowchart proposed in the Preferred Reporting Items for Systematic Reviews and Meta-Analyses (PRISMA) recommendations 


\begin{tabular}{|c|c|c|c|c|c|}
\hline $\begin{array}{l}\text { Author } \\
\text { and year }\end{array}$ & $\begin{array}{c}\text { Origin/ } \\
\text { Language }\end{array}$ & Objectives & $\begin{array}{l}\text { Methodological } \\
\text { outlining }\end{array}$ & Results & Evidence \\
\hline $\begin{array}{l}\text { Krogh et al, } \\
2015^{(6)}\end{array}$ & $\begin{array}{l}\text { Australia/ } \\
\text { English }\end{array}$ & $\begin{array}{l}\text { To examine the } \\
\text { perception of } \\
\text { health professionals } \\
\text { regarding the } \\
\text { video-assisted } \\
\text { debriefing technique. }\end{array}$ & $\begin{array}{l}\text { Descriptive study with } \\
\text { a qualitative approach, } \\
\text { analyzed through Thematic } \\
\text { Analysis. It approached } \\
24 \text { professionals from the } \\
\text { Australian health team, } \\
\text { about the video assisted } \\
\text { debriefing technique in } \\
\text { the simulation. }\end{array}$ & $\begin{array}{l}\text { Four categories were identified: (1) how and when the } \\
\text { simulation instructors use the video for debriefing - using it } \\
\text { in clippings, exposed before the discussion; (2) impact of the } \\
\text { video-assisted debriefing technique on learning - considered } \\
\text { positive (3) educational approaches to the video debriefing } \\
\text { technique - performed using pre-established scripts and } \\
\text { protocols; (4) benefits- the main one being the visualization of } \\
\text { behavior and challenges- the exposure } \\
\text { of the participants. }\end{array}$ & 6 \\
\hline Ha et al, 2014 & $\begin{array}{l}\text { South } \\
\text { Korea/ } \\
\text { English }\end{array}$ & $\begin{array}{l}\text { To identify attitudes } \\
\text { towards the video- } \\
\text { assisted debriefing } \\
\text { technique in a } \\
\text { nursing simulation. }\end{array}$ & $\begin{array}{l}\text { A descriptive, quantitative } \\
\text { and qualitative study that } \\
\text { used the "Q methodology" } \\
\text { to analyze the characteristics } \\
\text { and perceptions of } 44 \\
\text { nursing students from a } \\
\text { university in South Korea } \\
\text { about the video-assisted } \\
\text { debriefing technique. }\end{array}$ & $\begin{array}{l}\text { The results were placed under three categories; (1) the } \\
\text { video-assisted debriefing technique assists in self-reflection; } \\
\text { (2) the video-assisted debriefing technique can cause } \\
\text { exposure and humiliation for the participants; (3) the video- } \\
\text { assisted debriefing technique increases self-confidence. It } \\
\text { was noted that, in general, the video-assisted debriefing } \\
\text { technique improves both the technique and attitude of the } \\
\text { nursing student. }\end{array}$ & 6 \\
\hline $\begin{array}{l}\text { Gamboa et } \\
\text { al, 2018 }\end{array}$ & $\begin{array}{l}\text { Colombia/ } \\
\text { English }\end{array}$ & $\begin{array}{l}\text { To compare the } \\
\text { effectiveness of } \\
\text { oral debriefing } \\
\text { and the video- } \\
\text { assisted debriefing } \\
\text { technique for the } \\
\text { development } \\
\text { of neonatal } \\
\text { resuscitation skills } \\
\text { in nursing. }\end{array}$ & $\begin{array}{l}\text { Experimental, randomized } \\
\text { study carried out with } \\
24 \text { professionals from } \\
\text { the health team in a } \\
\text { university hospital in } \\
\text { Colombia. One group } \\
\text { received oral debriefing } \\
\text { (control) and the other the } \\
\text { video-assisted debriefing } \\
\text { technique (intervention). }\end{array}$ & $\begin{array}{l}\text { Both strategies improve resuscitation skills, reaching } 100 \% \\
\text { compliance in the third scenario assessed. No significant } \\
\text { differences were found between the two discussion strategies. } \\
\text { The coefficient of difference in skills improvement percentage } \\
\text { between the two types of debriefing was -3.6\% (95\% } \\
\text { confidence interval). Presenting 6,34\% for oral debriefing and } \\
-0.19 \% \text { for the video-assisted technique. }\end{array}$ & 2 \\
\hline
\end{tabular}

Chart 1 - Characterization of the articles that comprised the sample 


\begin{tabular}{|c|c|c|c|c|c|}
\hline $\begin{array}{l}\text { Author } \\
\text { and year }\end{array}$ & $\begin{array}{l}\text { Origin/ } \\
\text { Language }\end{array}$ & Objectives & $\begin{array}{l}\text { Methodological } \\
\text { outlining }\end{array}$ & Results & Evidence \\
\hline Jacobs, $2017^{(21)}$ & $\begin{array}{l}\text { United } \\
\text { States/ } \\
\text { English }\end{array}$ & $\begin{array}{l}\text { To explore the } \\
\text { performance of the } \\
\text { nursing team using } \\
\text { the video-assisted } \\
\text { debriefing technique. }\end{array}$ & $\begin{array}{l}\text { A quasi-experimental, } \\
\text { before and after type } \\
\text { study, that evaluated the } \\
\text { knowledge of } 84 \text { nurses } \\
\text { during a simulation on } \\
\text { obstetric hemorrhage } \\
\text { using the video-assisted } \\
\text { debriefing technique. }\end{array}$ & $\begin{array}{l}16 \text { debriefing sessions were carried out, with a descriptive } \\
\text { record of the participants' responses, indicating generalized } \\
\text { unease during the visualization of the scenario through the } \\
\text { video-assisted debriefing technique, but appreciation for } \\
\text { observing their own performance and reflecting on their } \\
\text { actions. It was pointed out that good debriefing is by "thinking } \\
\text { out loud", being respectful, repeating and clarifying information } \\
\text { and being able to ask questions. } \\
\text { In post-simulation research, the majority of participants } \\
\text { indicated a rating of } 5=\text { totally agree or } 4=\text { agree, in the four } \\
\text { questions asked about debriefing, which were worth } 5 \text { points } \\
\text { each. The averages ranged from } 4.3 \text { to } 4.5 \text { correct answers. }\end{array}$ & 3 \\
\hline $\begin{array}{l}\text { Megel et } \\
\text { al, 2013(22) }\end{array}$ & $\begin{array}{l}\text { United } \\
\text { States/ } \\
\text { English }\end{array}$ & $\begin{array}{l}\text { To identify the } \\
\text { behavior of nursing } \\
\text { students using } \\
\text { the video-assisted } \\
\text { debriefing technique. }\end{array}$ & $\begin{array}{l}\text { A quasi-experimental study } \\
\text { carried out with nursing } \\
\text { students at an American } \\
\text { university, using the } \\
\text { video-assisted debriefing } \\
\text { technique to identify patient } \\
\text { safety behavior. }\end{array}$ & $\begin{array}{l}\text { After performing the video-assisted debriefing technique } \\
\text { with } 52 \text { students (100\%), } 84.6 \% \text { of them correctly mentioned } \\
\text { the need to wash their hands before providing care. Only } \\
46 \% \text { considered raising the head of the patient's bed and } \\
\text { identified errors in the intravenous infusion. } 34.6 \% \text { of students } \\
\text { did not wear gloves to provide direct assistance, and } 34.6 \% \\
\text { did not assess the characteristics of the wounds. The video } \\
\text { recordings highlighted behaviors that need more teaching } \\
\text { and reinforcement for best pediatric practices. }\end{array}$ & 3 \\
\hline $\begin{array}{l}\text { MacLean et } \\
\text { al, 2019(23) }\end{array}$ & $\begin{array}{l}\text { Australia/ } \\
\text { English }\end{array}$ & $\begin{array}{l}\text { To explore the } \\
\text { perceptions of } \\
\text { nursing students } \\
\text { about their } \\
\text { experience } \\
\text { after using the } \\
\text { video-assisted } \\
\text { debriefing technique. }\end{array}$ & $\begin{array}{l}\text { A qualitative study that } \\
\text { analyzed the perception of } \\
141 \text { students from a nursing } \\
\text { course at an Australian } \\
\text { university, divided into } 3 \\
\text { groups for debriefing. }\end{array}$ & $\begin{array}{l}\text { Six themes were identified, namely: (1) realism, (2) non-verbal } \\
\text { communication, (3) verbal communication skills, (4) reflective } \\
\text { learning, (5) becoming a nurse and (6) the patient's needs. } \\
\text { Through the analysis of these categories, it was possible to } \\
\text { report that video-assisted reflection results in a high level of } \\
\text { self-awareness, confidence and a sense of achievement. }\end{array}$ & 6 \\
\hline
\end{tabular}

Chart 1 - Cont.

Source: Research data, 2019. 


\section{Definition}

Use of audiovisual capture from simulation for debriefing, to support learning, allow students to see and hear their own performance, and identify needs for improvement ${ }^{(6,22-23)}$

\section{Objectives}

To visualize student performance, looking for specific behaviors, reflect and develop competence ${ }^{(6,20)}$.

Basic audiovisual capture (smartphone, or camcorder, or complex audiovisual capture): centers with complex mannequins, associated with digital outputs, multiple cameras and

Material resources microphones for recording audio and photos stored on a hard disk using a converter, which mixes the mannequin and information with synchronized images and audio ${ }^{(6)}$.

Considerations for performing the assisted video debriefing technique:

(1) The video recording equipment must be set before each simulation, to guarantee the quality.

(2) Students need to be informed during the briefing/pre-briefing of the intended capture, how it will be used and consent to this.

(3) The technique must be performed by a specialized technician.

(4) Participants must be taken to the debriefing room, arranged in chairs in a semicircle.

(5) The recording device must be connected to the laptop and projected on a screen.

(6) Debriefing must be double or triple the scene, in relation to time. The debriefing usually lasts

Procedure 20 to 50 minutes when using video

(7) Viewing the entire video is less common. If this occurs, the facilitator must stop the video to allow discussion of relevant points. It is recommended to expose segments or clippings of the video and highlight the learning objectives. Use short and limited clips (one to three).

(8) The video can be exposed after the debriefing reaction phase, or before the start of the debriefing. It is recommended the video be exposed after the reaction phase.

Highlight to the video debriefing period. The choice to use the entire video or clippings and the debriefing period in which the video will be spent ${ }^{(6.21)}$.

The main benefit is immediate recognition of behaviors that require changes after viewing the video about yourself or your peers.

Other benefits: improved debriefing by viewing the video, evaluation of actions and improvement in clinical thinking processes, identification of critical interventions and nursing skills through self-reflection and the development of clinical judgment, event recall

\section{Benefits} to improve the learning process and allow the creation of an intervention record, analysis of the video by the facilitators to assess whether all students participated, increased students' self-confidence and self-reflection; reducing memory bias and providing evidence of actions during the simulated scenario; improvement of teamwork and communication between the interdisciplinary team; improvement of results for patients $(7,21,23)$.

Main challenge: the video can make debriefing tiring and humiliating. Other challenges: distractions during the debriefing process, dependence on an audiovisual

Challenges mediator, the risk of being punitive and harming students; the decision to only show clippings of the video can generate a bias regarding the instructor's perspective during debriefing ${ }^{(6,7,23)}$.

Chart 2 - Characterization of the elements that make up the video-assisted debriefing technique, benefits and challenges of its application Source: Research data, 2019. 


\section{DISCUSSION}

Scientific production about the VAD technique, specifically about its elements, was considered incipient for this research. It may be contradictory to view the current literary collection on the VAD technique and to affirm that there are few studies in this scope, however, the number of studies that aim to describe the components that, in fact, make this technique feasible is scarce ${ }^{(6,20,23)}$, which justifies the small sample of this research.

Publications on the theme are exclusively of international, starting in 2013, characterizing the recent motivation to understand the elements present in the technique ${ }^{(22)}$.

A balance in the study evidence level classification that comprised the sample of this review is evidenced, dividing it between experimental and quasi-experimental studies (20-22), and qualitative approach research ${ }^{(6,7,23)}$. The quasi-experimental studies identified demonstrated that the VAD technique is effective for the development of clinical skills in nursing ${ }^{(21-22)}$. The only experimental study that compared the oral debriefing technique and the video technique, describing its elements and procedure, did not show statistically significant results, concluding that there is no superiority of one over the other ${ }^{(20)}$.

An integrative review study, which addressed the effectiveness of the VAD technique, identified mixed and few conclusive results related to the effectiveness for learning ${ }^{(24)}$. Corroborating this statement, an integrative review survey pointed out that, although widely recommended by the literature, several investigations on the VAD technique failed to prove its educational benefits ${ }^{(8,25)}$. This scenario points to the need for scientific deepening on the use of the VAD technique for nursing education.

Three domains were categorized to understand the characteristics related to the VAD technique:"Elements that make up the video-assisted debriefing technique";" "Benefits of using the video-assisted debriefing technique" and "Challenges of using the video-assisted debriefing technique".

The first category identified the four main components. Among them, the concept and objectives of the technique, which are articulated considering the meaning of visualizing the individual's performance, aiming to remind and evaluate him $^{(6,20,22-23)}$. The VAD technique favors the observation of behaviors more accurately, since the participant does not need to keep reminding himself how he acted and when he acted, which facilitates the development of critical thinking and skill development ${ }^{(26)}$.
The element "Material resources" clarified that the audiovisual capture can be simpler or more complex, the latter requiring technical expertise and more specific technology ${ }^{(6)}$. A recent literature review pointed out that the reflections made through the use of video during health simulations require hard technology and available and trained human resources, which is not always the reality of educational or health institutions, especially in the Brazilian reality ${ }^{(27)}$.

Considerations were identified in the literature for the judicious use of the VAD technique, highlighting the ideal time for performing the video debriefing; the choice to use the entire video or clippings for debriefing; and the best debriefing period for the video to be exposed to participants.

The literature indicates that, if the VAD technique is chosen, the debriefing will possibly be longer - usually lasting two to three times longer than the scenario, from 20 to 50 minutes. Therefore, due to time, it is necessary to select clippings that make a great discussion feasible, as viewing the entire video is not always possible, making it tiring for students $(8,20,23)$.

There are two possibilities: either moments for displaying the video before the debriefing reaction phase or after the reaction phase, when moods and emotions are more aligned and calmed ${ }^{(8,13)}$.

Regarding the domain "Benefits of using the assisted video debriefing technique", several benefits were identified from the adoption of the VAD technique, with emphasis on the immediate recognition of behaviors that require changes after viewing the video. The success and benefit of using the VAD technique depend more on the facilitator/instructor's expertise and experience, than, in fact, on the use of the video. Demonstrating the participant's performance is useful and can favor learning, however, the use of its benefits will be exponential if this reflection is conduced and carried out properly ${ }^{(25)}$.

Challenges were also pointed out in line with the third domain, "Challenges of using the video-assisted debriefing technique", emphasizing that, in the absence of appropriate pedagogical care, the video can make the debriefing tiring and humiliating for the participant.

A study carried out on the VAD technique at a university in South Korea with 44 nursing students found that, if the facilitator does not have a respectful and ethical attitude, students can feel exposed and humiliated when viewing their behavior. Thus, it is essential to train professionals for debriefing ${ }^{(7)}$. 
The main limitations of this study were the small number of studies that addressed the elements of the VAD technique for nursing learning, and the lack of methodological clarity in the design of certain studies.

Therefore, the choice of using the VAD technique is a matter of balance between its benefits and challenges, which vary according to the style and expertise of facilitators, the quality of the audiovisual system, the educational style adopted, the objectives of the simulation and the characteristics of the learner ${ }^{(6)}$.

\section{$\square$ CONCLUSION}

The production of scientific knowledge about the elements that make up the video-assisted debriefing technique is still incipient, of an international and recent nature, being divided into experimental or quasi-experimental studies with a qualitative approach.

Three categories were elaborated on the composition of the video-assisted debriefing technique: the elements, benefits and challenges. The composing elements of the technique were the concept, the objectives, the material resources and the ideal procedure to carry it out, with emphasis on the time taken to perform the video debriefing, the choice to use it in full or only clippings, and the best time for the video to be shown. The main benefit was the immediate recognition of behaviors that require changes and, as a challenge, the use of video that can generate tiredness or humiliation.

This research contributes to teaching, research and assistance within the scope of nursing simulation, by identifying and provoking reflection on the potential and weaknesses in the adoption of this debriefing technique for the teaching and learning process and highlighting its elements, which makes excellence in execution possible.

\section{REFERENCES}

1. Rodrigues CC, Carvalho DP, Salvador PT, Medeiros SM, Menezes RM, Ferreira Júnior $M A$, et al. Innovative nursing education from the perspective of epistemologies of the South. Esc Anna Nery. 2016;20(2):384-9. doi: https:// doi.org/10.5935/1414-8145.20160053

2. Tyerman J, Luctkar-Flude M, Graham L, Coffey S, Olsen-Lynch E. A systematic review of health care presimulation preparation and briefing effectiveness. Clin Simul Nurs. 2019;27:12-25. doi: https://doi.org/10.1016/j.ecns.2018.11.002

3. Palaganas JC, Fey M, Simon R. Structured debriefing in simulation-based education. AACN Adv CritCare. 2016;27(1):78-85. doi:https://doi.org/10.4037/ aacnacc2016328
4. Waznonis AR. Methods and evaluations for simulation debriefing in nursing education. J Nurs Educ. 2014;53(8):459-65. doi: https://doi. org/10.3928/014834-20140722-13

5. Rossignol M. Effects of video-assisted debriefing compared with standard oral debriefing. Clin Simul Nurs. 2017;13(4):145-53. doi: https://doi.org/10.1016/j. ecns.2016.12.001

6. Krogh K, Bearman M, Nestel D. Expert practice of video-assisted debriefing: an Australian qualitative study. Clin Simul Nurs. 2015;11(3):180-7. doi: https:// doi.org/10.1016/j.ecns.2015.01.003

7. Há E. Attitudes toward video-assisted debriefing after simulation in undergraduate nursing students: an application of $\mathrm{Q}$ methodology. Nurse Educ Today. 2014;34(6):978-84. doi: https://doi.org/10.1016/j.nedt.2014.01.003

8. Sawyer T, Eppich W, Brett-Fleegler M, Grant V, Cheng A. More than one way to debrief: a critical review of healthcare simulation debriefing methods. Simul Healthc. 2016;11(3):209-17. doi: https://doi.org/10.1097/ SIH.0000000000000148

9. Cheng A, Morse KJ, Rudolph J, Arab AA, Runnacles J, Eppich W. Learnercentered debriefing for health care simulation education: lessons for faculty development. Simul Healthc. 2016;11(1):32-40. doi: https://doi.org/10.1097/ SIH.0000000000000136

10. Levett-Jones T, Lapkin S. A systematic review of the effectiveness of simulation debriefing in health professional education. Nurse Educ Today. 2014.34(6): e5863. doi: https://doi.org/10.1016/j.nedt.2013.09.020

11. Savoldelli GL, Naik VN, Park J, Joo HS, Chow R, Hamstra SJ. Value of debriefing during simulated crisis management: oral versus video-assisted oral feedback. Anesthesiology. 2006;105(2):279-85. doi: https://doi. org/:10.1097/00000542-200608000-00010

12. Sawyer T, Sierocka-Casteneda A, Chan D, Berg B, Lustik M, Thompson M. The effectiveness of video-assisted debriefing versus oral debriefing alone at improving neonatal resuscitation performance: a randomized trial. Simul Healthc. 2012;7(4):213-21. doi: https://doi.org/10.1097/SIH.0b013e3182578eae

13. Grant VJ, Robinson T, Catena H, Eppich W, Cheng A. Difficult debriefing situations: a toolbox for simulation educators. Med Teach. 2018;40(7):703-12. doi: https://doi.org/ 10.1080/0142159X.2018.1468558

14. Royle C, Hargiss K. Comparison of baccalaureate nursing students' experience of video-assisted debriefing versus oral debriefing following high-fidelity human simulation. Int J Strat Inform Technol Applic. 2015;6(2):40-9. doi: https://doi. org/10.4018/978-1-5225-5490-5.ch014

15. Ganong LH. Integrative reviews of nursing research. Res Nurs Health.1987;10(1):1-11. doi: https://doi.org/10.1002/nur.4770100103

16. Ouzzani M, Hammady H, Fedorowicz Z, Elmagarmid A. Rayyan - a web and mobile app for systematic reviews. Syst Rev. 2016;5(1):210. doi: https://doi. org/10.1186/s13643-016-0384-4

17. Ursi ES, Galvão CM. Prevenção de lesões de pele no perioperatório: revisão integrativa da literatura. Rev Latino-Am Enfermagem. 2006;14(1):124-31. doi: https://doi.org/10.1590/S0104-11692006000100017

18. Melnyk BM, Fineout-Overholt E. Evidence-based practice in nursing \& healthcare: a guide to best practice. 2. ed. Philadelphia: Wolters Kluwer/ Lippincott Williams \& Wilkins; 2011.

19. Moher D, Liberati A, Tetzlaff J, Altman DG, The PRISMA Group. Preferred reporting items for systematic reviews and meta-analyses: the PRISMA statement. Int J Surg. 2010;8(5):336-41. doi: https://doi.org/10.1016/j.ijsu.2010.02.007 
20. Gamboa OA, Agudelo SI, Maldonado MJ, Leguizamón DC, Sandra M. C. Evaluation of two strategies for debriefing simulation in the development of skills for neonatal resuscitation: a randomized clinical trial. BMC Res Notes. 2018; 11:739. doi: https://doi.org/10.1186/s13104-018-3831-6

21. Jacobs PJ. Using high-fidelity simulation and video-assisted debriefing to enhance obstetrical hemorrhage mock code training. J Nurses Prof Dev. 2017;33(5):234-9. doi: https://doi.org/10.1097/NND.0000000000000387

22. Megel ME, Bailey C, Schnell A, Whiteaker D, Vogel A. High-fidelity simulation: how are we using the videos? Clin Simul Nurs. 2013;9: e305-e310. doi: https:// doi.org/10.1016/j.ecns.2012.04.003

23. MacLean S, Geddes F, Kelly M, Della P. Video reflection in discharge communication skills training with simulated patients: a qualitative study of nursing students' perceptions. Clin Simul Nurs. 2019; 28:15-24. doi: https://doi. org/10.1016/j.ecns.2018.12.006
24. Ali AA, Miller ET. Effectiveness of video-assisted debriefing in health education: an integrative review. J Nurs Educ. 2018:57(1):14-20. doi: https://doi. org/10.3928/01484834-20180102-04

25. Zhang H, Mörelius E, Goh SHI, Wang W. Effectiveness of video-assisted debriefing in simulation-based health professions education: a systematic review of quantitative evidence. Nurse Educ. 2019;44(3): E1-E6. doi: https:// doi.org/10.1097/NNE.00000000000000562

26. Reiersona IA, Haukedala TA, Hedemana H, Bjørk IT. Structured debriefing: what difference does it make? Nurse Educ Pract. 2017; 25:104-10. doi: https://doi. org/10.1016/j.nepr.2017.04.013

27. Pastor Júnior AA, Tavares CMM. Literature review of audiovisual practices in Nursing education. Rev Bras Enferm 2019;72(1):190-9. doi: http://doi. org/10.1590/0034-7167-2017-0890

\section{- Corresponding author:}

Juliana da Silva Garcia Nascimento

E-mail: mestradounesp28@yahoo.com.br

\section{Associate editor:}

Cecília Helena Glanzner

\section{Editor-in-chief:}

Maria da Graça Oliveira Crossetti 